\title{
Evaluation of First Normal Stress Difference from Resistant Force Acting on Inner Cylinder of Concentric Cylinder Flow Cell Descending with a Constant Speed \\ $-1^{\text {st }}$ Report: Calculation Method Based on Resistant Force in Steady State -
}

Yukinobu Sugihara, Takashi Yamauchi, and Tsutomu TAKAHASHI ${ }^{\dagger}$

Department of Mechanical Engineering, Nagaoka University of Technology 1608-1 Kamitomioka, Nagaoka, Niigata 940-2188, Japan

\begin{abstract}
A measurement technique for the first normal stress difference using a conventional rheometer with a concentric cylinder flow cell is examined. The conventional rheometer, which can control the up and down speeds of an inner cylinder of the concentric cylinder flow cell and can also measure the thrust force, is used in this technique. The other additional instruments or the optional devices are not required. The inner cylinder is pushed down with a constant velocity into the sample filled in the cup. The resistant force acting on the inner cylinder is measured during this motion. The resistant force is caused by the buoyancy, the shear stress acting on the side surface of the inner cylinder and the pressure acting on the top and bottom of the inner cylinder. The buoyancy and the shear stress can be calculated based on the shape of the inner cylinder and the moving velocity. If the inlet and outlet pressure drop can be ignored, the pressure caused by the first normal stress difference can be evaluated from the thrust force and the shear viscosity.
\end{abstract}

Key Words: First normal stress difference / Concentric cylinder flow cell / Steady state / Rheometry

\section{同心二重円筒流路の押し込み流れにおいて内円筒に作用する 抗力を利用した第一法線応力差の測定 \\ 一第 1 報：定常状態における押し込み反力に基づく算出方法一}

\author{
杉原 幸信, 山内 崇嗣, 高橋 勉
}

（原稿受理：2017 年 11 月 17 日）

\section{1. 緒 言}

高分子溶液などの粘弾性を示す流体はせん断流動により ニュートン流体では発生しない法線応力効果を示す1). 特に 第一法線応力差は粘弾性流体の特徵的な流動であるワイセン ベルグ効果 ${ }^{2)}$ やバラス効果 ${ }^{2)}$ などの発生に直接関係する。し たがって, 粘弾性を示す流体を取り扱うために第一法線応力 差の測定は不可欠である.

第一法線応力差の測定方法として最も一般的なのはトータ ル・スラスト法 ${ }^{3)}$ である。これは回転型レオメータに円錐円 板型流路を組み合わせた方法である。 円錐円板型流路の間に 挿入された試料は円錐あるいは円板の回転により，流路内全 体にわたってせん断速度一定のせん断変形を受ける。これに より第一法線応力差が生じ, 円形の流路においてそれはたが 応力として作用する. たが応力は流路中心に向かって締め付 け力を発生させる応力であり, 結果として円錐と円板は押し

$\dagger$ E-mail : ttaka@nagaokaut.ac.jp, Tel : +81-258-47-9728, Fax : +81-258-47-9770 長岡技術科学大学

†940-2188＼cjkstart新潟県長岡市上富岡町1603-1
広げられる方向の力を受けることになる。これをスラスト力 として測定することにより法線応力を評価する。したがって， 第一法線応力差を測定できるレオメータではせん断粘度評価 用トルク測定器に加えてスラスト力測定器を備えている。 ま た, 円錐円板型流路では円錐と円板の間隔を厳密に調整する 必要があるため, レオメータには回転軸を繊細に移動させる 上下微動機構と正確な位置センサーが搭載されている。各レ オメータ製造会社の技術力の向上は著しく, 測定器の精度の 向上や回転軸用のモー夕の回転安定性, 作動回転数の広帯域 化などの改良が日々進んでいる。 上下微動機構についても高 精細化されており, 流路のすき間調整や実験シーケンスの自 動化も図られ非常に使いやすくなっている.

このように大きく性能が向上している回転型レオメータで あるが, 回転型であるため高いせん断速度領域では遠心力に より円錐円板型流路内に試料を保持できないこと，第一法線 応力差が非常に小さい粘弾性流体や低粘度流体に対しては適 応が難しいことなどの問題がある。これらの問題に対応した 測定方法はいくつか開発されてきた。例えば，流動複屈折 法) ${ }^{4)}$ (流動時に生じる複屈折の值から第一法線応力差を評価 する方法である. 光弾性則に従う試料に限定されるが第一法 
線応力差の小さい粘弾性流体にも適用でき, さらに, 機械的 な応答の遅れがないため非定常状態でも測定できるという利 点がある。また, 長谷川が開発したジェットスラスト法は低 粘度流体の高せん断速度領域における第一法線応力差測定に 関して有効な方法として知られている

これらに対し, 著者らは既存の回転型レオメータをそのま ま用いて第一法線応力差を測定できる新たな測定手法を模索 している. その一つとして同心二重円筒流路の内円筒を試料 中に押し込み, 内円筒に作用する反力から第一法線応力差を 評価する手法を考案した。 上述のとおり現在の回転型レオ メータには回転軸に沿った上下微動機構とスラスト力に対す る高感度測定器が内蔵されている。したがって, これらをそ のまま利用し, 回転型レオメータをスライド型レオメータと して使用する。ささらに, 回転型レオメータに付随している同 心二重円筒流路の内円筒をそのまま無改造で押し込み用のボ ブとして使用する。この手法ではカップを用いるため流動性 の高い試料に対応できる. また, スラスト力測定器の力を検 出する方向とボブの移動する方向が同じになるため第一法線 応力差の評価に用いる力の検出感度が向上し, 通常よりも低 いせん断速度領域に適用できると期待される。

この同心二重円筒流路を用いた第一法線応力差の測定技術 について, 本報告では回転型レオメータを内円筒ボブの押し 込み動作で測定するスライド型レオメータに転用し, 押し込 みにより発生する反力のパターンを明らかにする。さらに， 定常状態における押し込み反力から第一法線応力差を見積も る簡易解析手法を示す。そして, トータル・スラスト法に よって評価した第一法線応力差と比較することにより, 本手 法の妥当性を検討する.

\section{2. 実験装置および試料}

\section{1. 実験装置}

実験用プラットフォームとしてひずみ制御型レオメータ ARES-LS（TA Instruments 社）を用いた. Fig. 1(a)に使用し た同心二重円筒流路の概略図を示す。また, Table I に流路 の寸法を示す．長さの異なる三種類の内円筒ボブを用意した. これらを $L=15, L=25, L=33$ と呼ぶ.

\section{2. 試料}

ニュートン流体として粘度計校正用標準液である JS100 お よびJS2000を用いた。 また, 粘弾性流体としてせん断粘度 と第一法線応力差がべき乗則に従うポリアクリルアミド $0.2 \mathrm{wt} \%$ 水溶液（以後, PAA0 $2 \mathrm{wt} \%$ と呼ぶ）を使用した.

Fig. 2 にARES-LS に直径 $25 \mathrm{~mm}$ の円錐円板型流路を取り付 けて測定したJS100, JS2000 およびPAA0.2 wt\%のレオロ ジー特性を示す.JS100 と JS2000のせん断粘度はそれぞれ 0.0702, $1.31 \mathrm{~Pa} \mathrm{~s}$ である。 また, 式（1）にべき乗則流体の構 成方程式を示す ${ }^{6}$. PAA0.2 wt\% をべき乗則流体と仮定して $0.05<\dot{\gamma}<500 \mathrm{~s}^{-1}$ の領域を近似した場合, 擬塑性粘度 $K$ と構 造粘度指数 $n$ はそれぞれ $K=0.849 \mathrm{~Pa} \mathrm{~s}{ }^{n}$, および, $n=0.378$ となる。液温は $25 \pm 1{ }^{\circ} \mathrm{C}$ とた。

$$
\tau=K|\dot{\gamma}|^{n-1} \dot{\gamma}
$$

Table I. Dimensions of the concentric cylinder flow cell.

\begin{tabular}{|l|l|}
\hline Radius of cup $R_{C}$ & $17.0 \mathrm{~mm}$ \\
\hline Radius of bob $R_{B}$ & $16.0 \mathrm{~mm}$ \\
\hline Radius of shaft $R_{S}$ & $6.35 \mathrm{~mm}$ \\
\hline Length of bob $L$ & $15.0,25.0,33.0 \mathrm{~mm}$ \\
\hline Gap between cup and bob $h$ & $1.0 \mathrm{~mm}$ \\
\hline
\end{tabular}

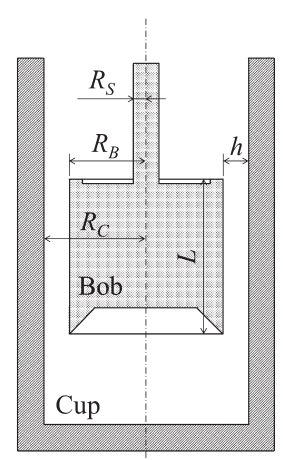

(a) Cross-section of flow cell

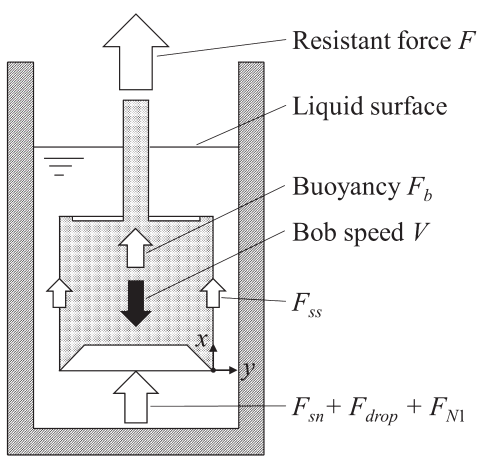

(b) Forces acting on bob
Fig. 1 Schematic diagrams of a concentric cylinder flow cell and forces acting on the bob.
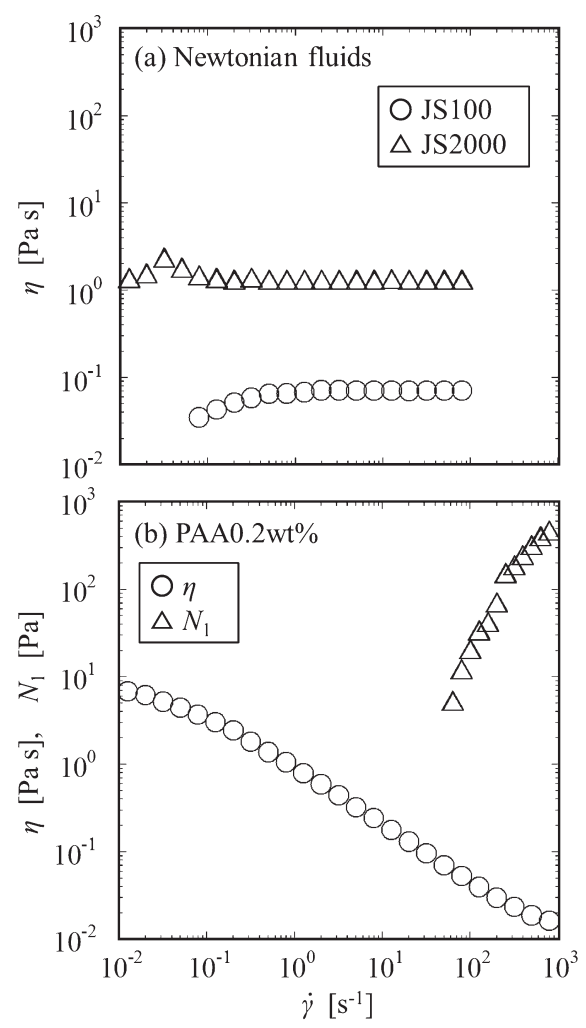

Fig. 2 Flow property as a function of the shear rate $\dot{\gamma}$. (a) The shear viscosity $\eta$ of the Newtonian fluids. (b) The shear viscosity $\eta$ and the first normal stress difference $N_{1}$ of PAA0.2 wt $\%$.

\section{3. 実験結果および考察}

\section{1. ボブの押し込み過程と反力の変化パターンについて}

カップに試料を満たして静止させる。 そして, 内円筒ボブ の底面が液面に接しない位置から一定の速度で押し下げる。 試料と接触後も等速で押し込みを続け, ある距離を移動させ 


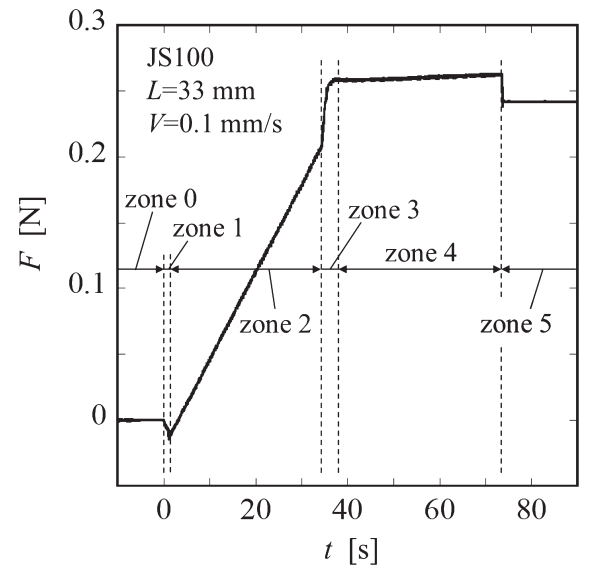

Fig. 3 Resistant force acting on the bob $F$ of JS100 at a constant speed $V=0.1 \mathrm{~mm} / \mathrm{s}$.

た後に停止させる。この一連の過程でボブに作用する反力 $F$ を測定した. Fig. 3 にJS100の測定結果を示す。ボブの押し 込み過程に基づき, 反力の変化パターンを 6 つの領域に分け ることができる。領域 0 はボブの底面が液面に接触していな い領域である。このときボブに作用する力を $F=0 \mathrm{~N}$ と定義 する。また，ボブが液面と接触した瞬間を基準時刻 $t=0 \mathrm{~s}$ と する。この瞬間にボブとカップのすき間において毛管力が発 生し, ボブを引き下げる力が生じる，さらに，ボブ底面のく ぼみ部分においては，試料がくぼみ内壁面を這い上がるため 所定の接触角を伴う気泡が形成される。この際にも表面張力 に係わる引き下げ力が発生する。これらのボブを引き下げる 力はすぐに定常に達するため, ボブの押し込みが進むと押し 达み量に比例して発生する押し上げ力が支配的な状態に移行 する。そこで，ボブが液面に接触して引き下げ力が支配的な 状態を領域 1 とし, 押し込み量と押し上げ力が比例する状態 を領域 2 とする。領域 2 では試料液面はボブの沈降に合わせ てボブとカップの側面のすき間を一定速度で上昇する。濡れ 面積の増加に伴ってボブ底面に作用する圧力による押し上げ 力, ボブ側面に作用するせん断応力による押し上げ力, およ び，ボブ上面に作用する圧力による押し下げ力の 3 つの力が 時間に比例して増加する. そのため, $F$ は時間に比例して一 様に増加する。 その後, 液面がボブの上端を超えると $F$ は ステップ的に大きくなる。これはすき間から流出した試料が ボブの末端にピン止めされたままカップ側面を這い上がり, ボブが上方へ引つ張られるためだと考えられる。これを領域 3 とする。試料の液面がボブの上面を覆い尽くしたあとはボ ブのシャフト部が試料に押し达まれる量にしたがって浮力が 増加する。これを領域 4 とする。 ボブの移動を急停止すると $F$ は低下し, ボブに作用している浮力の值を示して一定とな る。これを領域 5 とする。本報告では領域 4 の定常状態にお いてボブに作用する押し込み反力を用いた第一法線応力差の 算出方法について述べる.

\section{2. 領域 4 における反力の測定結果}

Fig. 4 に領域 4 における押し込み反力 $F$ の時間変化を示す. 試料はJS100 である. 流動開始前の状態を統一するためにボ ブの上面が試料液面より下となる位置まで押し込み, その後 一定時間静止させてから測定を開始した。 ボブを一定速度で

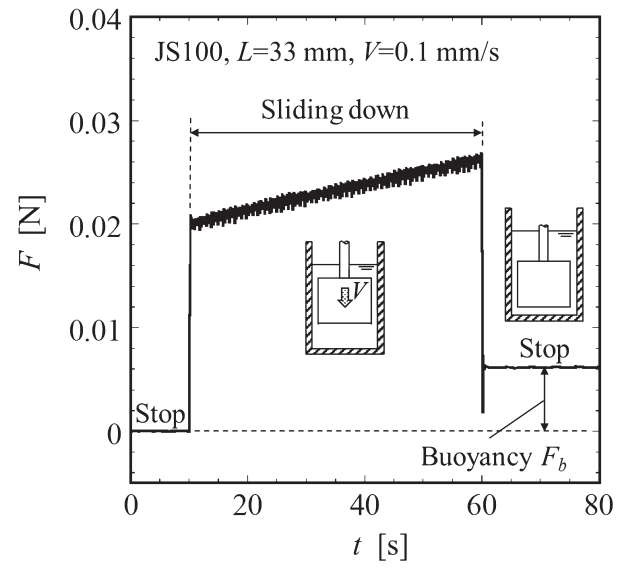

Fig. 4 Relationship between the resistant force acting on the bob $F$ and the time $t$ in the zone 4 .
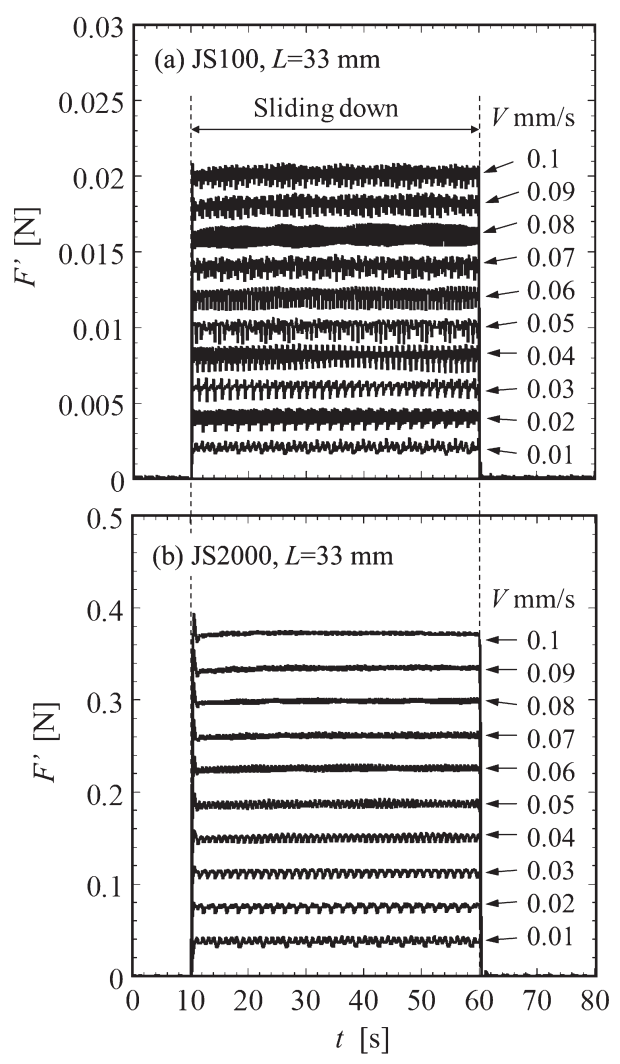

Fig. 5 Resistant force correcting a buoyancy $F^{\prime}$ of (a) JS100 and (b) JS2000 as a function of the time $t$.

降下させている過程では，ボブを支える中心軸が試料中に押 し込まれていくため浮力 $F_{b}$ が増加し， $F$ は時間に比例して 大きくなる。この状態からボブを停止すると $F$ は低下し, $F_{b}$ に相当する值を示して一定となる。この值を $F$ から引く ことで浮力を補正した反力 $F^{\prime}$ を得る。浮力の補正について は砲弾型ボブを流体内に押し込むときに発生する反力から平 面伸張粘度を測定した先行論文7)に詳細を記載している。

Fig. 5 にJS100 と JS2000，そして, Fig. 6 にPAA0.2 wt \% の浮力を補正した反力 $F^{\prime}$ の時間变化を示す。ニュートン流 体であるJS100 と JS2000の場合， $F_{b}$ を差し引いた $F^{\prime}$ は押し 込み過程で一定の值を保ち, 押し込み停止と同時にゼロに戻 
る。粘弾性流体である PAA0 $0.2 \mathrm{wt} \%$ の場合, ボブの押し込み 開始とともに $F^{\prime}$ はオーバーシュートした後, ほぼ一定の值 を保つ。ニュートン流体と異なり押し込み停止後の $F^{\prime}$ は PAA0.2 wt\% の緩和に依存して徐々にゼロに達する.

\section{3. 領域 4 でボブに作用する反力の簡易解析 : ニュート ン流体}

領域 4 においてボブとカップの側面によって構成されるす き間内の定常に達した流れ場を簡易的に解析する。ここで, 鈴木らは同心二重円筒流路の内円筒を微小距離移動させた際 に生じる反力を，壁面せん断応力による力とすき間内のせん 断変形に起因した圧力損失による力の合力と仮定して解析を 行うことにより，液状食品の粘性を評価した ${ }^{8,9)}$. そこで, 本報告ではこれらに加え入口・出口圧力損失および第一法線 応力差による影響も考慮して内円筒ボブに作用する反力の簡 易解析を行う.

ニュートン流体では第一法線応力差が生じないので, 浮力 を補正した反力 $F^{\prime}$ を式（2）のように仮定する（Fig. 1(b)).

$$
F^{\prime}=F-F_{b}=F_{s s}+F_{s n}+F_{d r o p}
$$

ここに, $F_{b}$ は浮力を示す. 式 $(3)$ より, 浮力は時間に比例 して増加する7).

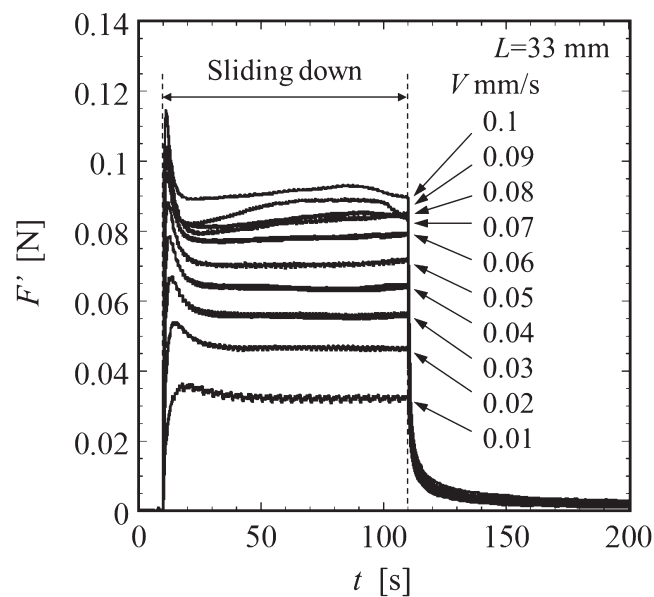

Fig. 6 Resistant force correcting a buoyancy $F^{\prime}$ of PAA $0.2 \mathrm{wt} \%$ as a function of the time $t$.

$$
F_{b}=\rho g \pi R_{S}{ }^{2}\left(1+\frac{R_{S}{ }^{2}}{R_{C}{ }^{2}-R_{S}{ }^{2}}\right) V t
$$

ボブとカップのすき間部ではボブの押し込みによる排除体積 にしたがって試料が上方に向かい流動する。この際，ボブと カップの側面の速度差に起因するクエット型のせん断変形と, ボブ下面の圧力上昇に起因するポアズイユ型のせん断変形の 2 つが合成された流れ場が形成される。ただし，ボブ底面の 断面積に対してボブとカップのすき間部の断面積が極めて小 さいことから，ポアズイユ型のせん断変形が支配的でありク エット型の成分は無視できるほど小さい。 また，今回の実験 ではボブの降下速度が非常に小さいため慣性力も無視できる. これより, ボブ底面の圧力増加はポアズイユ型のせん断変形 に伴う粘性損失が支配的となる。そこで， $F_{s s}$ をボブ側面に 作用する合成された流れ場のせん断応力 $\tau_{w}$ による力， $F_{s n}$ を ポアズイユ型のせん断変形に起因するボブ上下の圧力差によ る力と定義する.

$$
\begin{aligned}
& F_{s s}=\int_{0}^{L} \tau_{w} \times 2 \pi R_{B} \times d x=2 \pi R_{B} L \tau_{w} \\
& F_{s n}=\int_{0}^{L}\left(-\frac{d p}{d x}\right) d x \times \pi R_{B}{ }^{2}=\left(-\frac{d p}{d x}\right) L \pi R_{B}{ }^{2}
\end{aligned}
$$

ここに, $(-d p / d x)$ は $x$ 方向，すなわち，流れ方向の圧力こう 配である.さらに，式（6）によって示される $F_{\text {drop }}$ はすき間 の入口・出口圧力損失 $\Delta p_{\text {drop }}$ によって生じる力であり, バグ レイ・プロット ${ }^{3,10)}$ を応用した測定から得られる実験值を用 いて補正する。

$$
F_{d r o p}=\Delta p_{d r o p} \times \pi R_{B}^{2}
$$

ボブとカップの側面のすき間 $h$ はボブの半径 $R_{B}$ に対して 十分に小さいことから，すき間内の流れ場は二次元定常流れ で，かつ，ポアズイユ型のせん断流動が支配的と見なすこと ができる。また，すき間 $h$ を代表長さとしたレイノルズ数は $10^{-4}$ から $10^{-2}$ のオーダーである。このことから助走区間を無 視し，十分に発達した流れ場を想定した．Fig. 1(b) に示す ように内円筒ボブの下部端を座標原点とし, 流れ方向を $x$ 軸, 半径方向を $y$ 軸とした直交座標系を適用する。ニュートンの

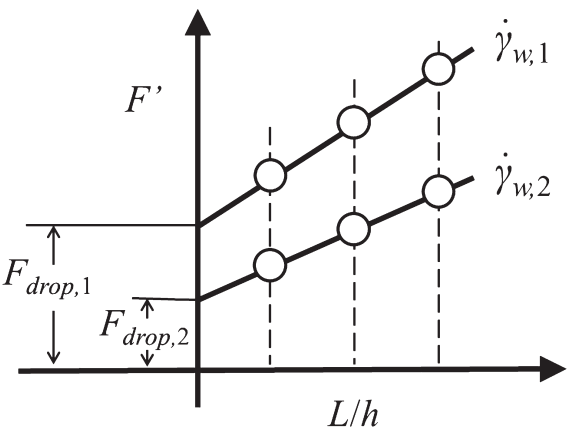

(b) Concentric cylinder flow cell

(a) Capillary 3), 10)

Fig. 7 Measurement of the inlet and outlet pressure drop using the Bagley plot ${ }^{3}$. 
粘性法則を考慮すると流れ場の運動方程式は式（7）で表さ れる。

$$
0=\left(-\frac{d p}{d x}\right)+\frac{d \tau}{d y}=\left(-\frac{d p}{d x}\right)+\eta \frac{d^{2} v_{x}}{d y^{2}}
$$

式（8）で示される境界条件（ボブ壁面で- $V$, カップ壁面で 速度ゼロ）を考慮することにより，速度分布 $v_{x}$ は式（9）と なる。ここに， $h=R_{C}-R_{B}$ である.

$$
\begin{aligned}
& \left\{\begin{array}{l}
y=0, v_{x}=-V \\
y=h, v_{x}=0
\end{array}\right. \\
& v_{x}=\frac{h^{2}}{2 \eta}\left(-\frac{d p}{d x}\right)\left\{\frac{y}{h}-\left(\frac{y}{h}\right)^{2}\right\}+V\left(\frac{y}{h}-1\right)
\end{aligned}
$$

したがって，平行平板間と仮定したすき間内の平均流速 倍は式（10）で示される.

$$
\overline{v_{x}}=\frac{1}{\pi\left(R_{B}+R_{C}\right) h} \int_{0}^{h} v_{x} \times \frac{2 \pi\left(R_{B}+R_{C}\right)}{2} \times d y=\frac{h^{2}}{12 \eta}\left(-\frac{d p}{d x}\right)-\frac{V}{2}
$$

一方で, $\overline{v_{x}}$ はボブの移動速度 $V$ から幾何学的に式 (11) で 算出できると仮定する.

$$
\overline{v_{x}}=\frac{\pi R_{B}^{2} V}{\pi\left(R_{B}+R_{C}\right) h}=\frac{R_{B}{ }^{2} V}{\left(R_{B}+R_{C}\right) h}
$$

式（10）と式（11）より，圧力こう配は式（12）で表される.

$$
\left(-\frac{d p}{d x}\right)=\frac{12 \eta V}{h^{3}}\left(\frac{R_{B}{ }^{2}}{R_{B}+R_{C}}+\frac{h}{2}\right)
$$

また，ボブ壁面におけるせん断速度 $\dot{\gamma}_{w}$ は式（13）となる。

$$
\dot{\gamma}_{w}=\frac{h}{2 \eta}\left(-\frac{d p}{d x}\right)+\frac{V}{h}
$$

ボブ壁面に作用するせん断応力 $\tau_{w}$ はニュートンの粘性法則 より式（14）で示すことができる。

$$
\tau_{w}=\eta \dot{\gamma}_{w}=\frac{h}{2}\left(-\frac{d p}{d x}\right)+\frac{V}{h} \eta
$$

これらを式（2）に代入することにより，ニュートン流体の 浮力を補正した反力 $F^{\prime}$ を簡易的に見積もることができる.

\section{4. 領域 4 でボブに作用する反力の簡易解析 : ベき乗則 流体}

同様の簡易解析をべき乗則流体に対して行う。Fig. 1 (b) より，べき乗則流体の $F^{\prime}$ を式（15）のように仮定する.

$$
F^{\prime}=F-F_{b}=F_{s s}+F_{s n}+F_{d r o p}+F_{N 1}
$$

ここで，すき間内の流れにおいて第一法線応力差は張力とし て作用することになりボブの側壁面に対しては直接的な力は 作用せず，入口側と出口側の圧力に対して影響を与える。す き間の出口部分では弾性力の回復のためにボブ上面の圧力が 増加し下向きの力が発生する。そして，すき間の入口近傍で は法線応力によってボブ下部の試料がすき間内へ引っ張られ ることにより圧力が低下すると考えられる。これらの現象は まだ解析的に正しい把握ができないため，本手法ではボブと カップのすき間におけるせん断流動によって生じた第一法線 応力差はボブの上下の間に圧力差を生み, ボブを下から上へ 押し上げる力 $F_{N 1}$ を発生させると仮定する。べき乗則流体の 流れ場の導出では，まずボブとカップが静止した状態の十分 に発達した二次元ポアズイユ流れとボブが速度 $-V$ で移動す るクエット流れを別々に導いた。そして，それらを足し合わ せることによって $0<y<h / 2$ の領域における二次元定常せん 断流れを得た。速度分布 $v_{x}$ は式（16）で表される.

$$
v_{x}=\frac{n}{n+1}\left\{\frac{1}{K}\left(-\frac{d p}{d x}\right)\right\}^{\frac{1}{n}}\left\{\left(\frac{h}{2}\right)^{\frac{n+1}{n}}-\left(\frac{h}{2}-y\right)^{\frac{n+1}{n}}\right\}+V\left(\frac{y}{h}-1\right)
$$

ここに，右辺第一項は十分に発達した二次元ポアズイユ流れ， 第二項はクエット流れの速度分布を示す。また，平均流 速 $\overline{v_{x}}$ は式（17）となる。

$$
\overline{v_{x}}=\frac{2 n}{(2 n+1) h}\left\{\frac{1}{K}\left(-\frac{d p}{d x}\right)\right\}^{\frac{1}{n}}\left(\frac{h}{2}\right)^{\frac{2 n+1}{n}}-\frac{V}{2}
$$

したがって, 式（11）と式（17）より，圧力こう配は式（18） で表される。

$$
\left(-\frac{d p}{d x}\right)=K\left[\frac{2 n+1}{n} \times \frac{V}{2} \times\left(\frac{2}{h}\right)^{\frac{2 n+1}{n}} \times\left\{\frac{R_{B}{ }^{2}}{R_{B}+R_{C}}+\frac{h}{2}\right\}\right]^{n}
$$

ボブ壁面におけるせん断速度 $\dot{\gamma}_{w}$ は式（19）となる。

$$
\dot{\gamma}_{w}=\left\{\frac{h}{2 K}\left(-\frac{d p}{d x}\right)\right\}^{\frac{1}{n}}+\frac{V}{h}
$$

よって，本報告では第一法線応力差 $N_{1}$ を式（20）より評価 する。

$$
N_{1}=\frac{F_{N 1}}{\pi R_{B}{ }^{2}}=\frac{F^{\prime}-\left(F_{s s}+F_{s n}+F_{d r o p}\right)}{\pi R_{B}{ }^{2}}
$$

\section{5. 入口・出口圧力損失による力の測定}

本報告ではバグレイ・プロット ${ }^{3,10)}$ の考えを用いて入口・ 出口圧力損失による力を測定する. Fig. 7(a)より, バグレ イ・プロットは長さの異なる同じ断面形状の細管で流量 $Q$ が一定となる点での圧力損失 $\Delta p$ を測定し，横軸に長さと半 径の比 $L / R$, 縦軸に圧力損失 $\Delta p$ のグラフを作成する。そし 
て, グラフの切片 $(L / R=0)$ の圧力損失 $\Delta p_{0}$ を入口 - 出口压 力損失とする手法である。 この考えを利用し, Fig. 7(b) の ように横軸にボブの長さとすき間の比 $L / h$, 縦軸に同じボブ 壁面せん断速度 $\dot{\gamma}_{w}$ における浮力を補正した反力 $F^{\prime}$ をる。 そして,$L / h=0$ のときの $F^{\prime}$ を口・出口圧力損失による力 $F_{d r o p}$ とし， $\dot{\gamma}_{w}$ との関係を求めた。 ここで，式 (13)，(19), （21）より, ボブ壁面せん断速度 $\dot{\gamma}_{w}$ とすき間に生じる流量 $Q$ は移動速度 $V$ の関数であり, 一意の $V$ が定まれば異なる $L / h$ においても一定の值を保つ。

$$
Q=\pi R_{B}^{2} V
$$

Fig. 8 にJS100 およびJS2000 のバグレイ・プロットの結果 を示す。これらの結果をもとにそれぞれのボブ壁面せん断速 度 $\dot{\gamma}_{w}$ の実験結果を線形近似し， $L / h=0$ における $F^{\prime}$ の值，す なわち, 入口・出口圧力損失による力 $F_{\text {drop }}$ を求めた. Fig. 9 にJS100 と JS2000における $F_{\text {drop }}$ と $\dot{\gamma}_{w}$ の関係を示す. 原点を 通過する一次関数と仮定して実験結果を近似すると, JS100 と JS2000 の入口・出口圧力損失による力 $F_{\text {drop }}$ は式 $(22)$ と 式（23）によって表すことができる.

$$
\begin{aligned}
& \text { JS100: } \quad F_{\text {drop }}=0.000197 \dot{\gamma}_{w} \\
& \text { JS2000: } \quad F_{\text {drop }}=0.00289 \dot{\gamma}_{w}
\end{aligned}
$$

同様の測定をPAA0.2 wt\% に対しても行った. Fig. 10 に PAA0.2 wt \% のバグレイ・プロットの結果を示す．また， Fig. 11
にPAA0.2 wt $\%$ における $F_{d r o p}$ と $\dot{\gamma}_{w}$ の関係を示す. 両者の関 係をべき関数と仮定して近似すると，PAA $0.2 \mathrm{wt} \%$ の入口・ 出口圧力損失による力 $F_{\text {drop }}$ は式 $(24)$ で示すことができる.

$$
\text { PAA0.2wt } \%: \quad F_{d r o p}=0.0138 \dot{\gamma}_{w}{ }^{0.319}
$$

\section{6. 実験値と簡易解析結果の比較}

ボブに作用する反力の実験值と簡易解析結果の比較を行う. ここで, 実験によって得た浮力を補正した反力 $F^{\prime}$ の平均值 を $F_{\text {exp. }}^{\prime}$, さらに, $F_{\text {exp }}^{\prime}$ から式 (22)，(23)，(24）に示される入 口・出口圧力損失による力 $F_{\text {drop }}$ を補正した反力を $\left(F^{\prime}-F_{\text {drop }}\right)_{\text {exp. }}$. と表記する. そして, 第一法線応力差の影響を含まない式 （25）より求められる值を簡易解析結果 $F^{\prime}{ }_{\text {calc }}$. とする. ここに, $F_{s s}$ と $F_{s n}$ には 3.3. 節および 3.4. 節で導いた值を用いる.

$$
F_{\text {calc. }}^{\prime}=F_{s s}+F_{s n}
$$

Fig. 12 にJS100 およびJS2000 の比較結果を示す. ニュー トン流体の場合，簡易解析結果 $F_{\text {calc. }}^{\prime}$ に対する実験值 $F_{\text {exp. }}^{\prime}$ の 相対誤差率はJS100において約 $5.7 \%$, JS2000において 約 $4.7 \%$ である。 これに対し, 入口・出口圧力損失による力 を補正した $\left(F^{\prime}-F_{\text {drop }}\right)_{\text {exp. }}$ ではそれぞれ約 $-1.5 \%$ および 約 $-1.1 \%$ となる. このことから, バグレイ・プロットの考え を用いた入口・出口圧力損失による力の測定方法はニュート ン流体に対して妥当であり,この力を考慮することによって 実験值と簡易解析結果がよく一致することが明らかとなった. 一方, Fig. 13 に示す PAA0.2 wt\% の場合, 実験值 $F_{\text {exp. およ }}^{\prime}$
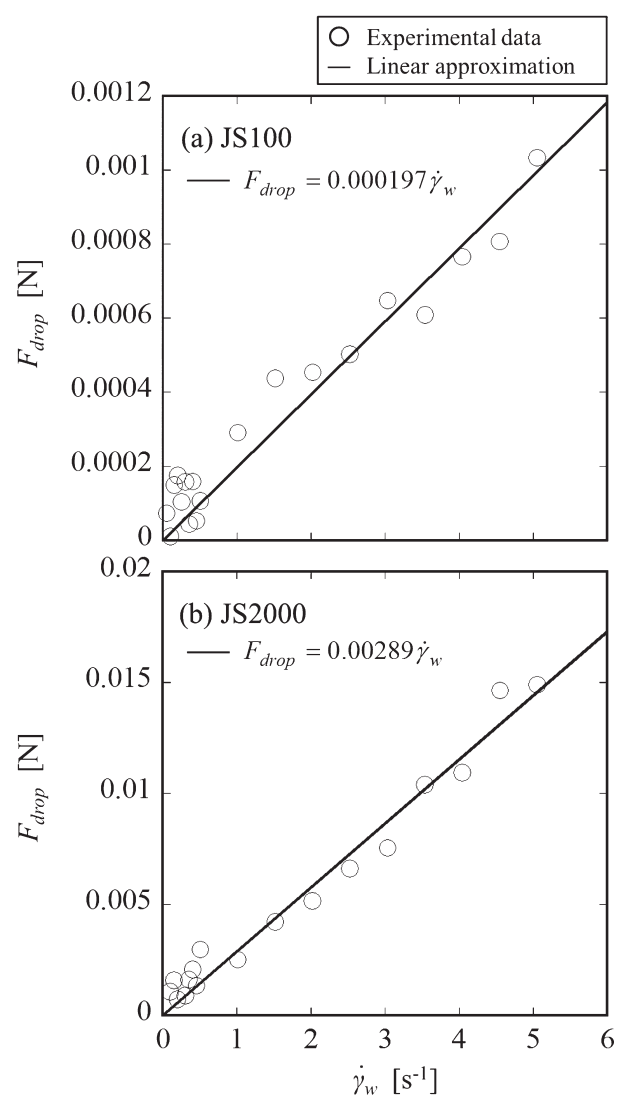

Fig. 9 Relationship between the force caused by the inlet and outlet pressure drop $F_{d r o p}$ and the shear rate at the wall $\dot{\gamma}_{w}$ of (a) JS100 and (b) JS2000. 
び $\left(F^{\prime}-F_{\text {drop }}\right)_{\text {exp. }}$ と簡易解析結果 $F_{\text {calc. }}^{\prime}$ には差が生じることが わかる。本手法ではこの差が第一法線応力差 $N_{1}$ の影響を表 している，したがって，式（25）を式（20）に代入すること により，式（26）を用いて第一法線応力差 $N_{1}$ を実験值から 算出する。

$$
N_{1}=\frac{F_{N 1}}{\pi R_{B}{ }^{2}}=\frac{F^{\prime}-\left(F_{s s}+F_{s n}+F_{\text {drop }}\right)}{\pi R_{B}{ }^{2}}=\frac{\left(F^{\prime}-F_{\text {drop }}\right)_{\text {exp. }}-F_{\text {calc. }}^{\prime}}{\pi R_{B}{ }^{2}}
$$

式（26）より， $\left(F^{\prime}-F_{\text {drop }}\right)_{\text {exp. }}>F_{\text {calc. }}^{\prime}$ において $N_{1}>0$ となる ことがわかる. しかし, Fig. 13 よりボブの長さを変更した すべての条件において $\left(F^{\prime}-F_{\text {drop }}\right)_{\text {exp. }}<F_{\text {calc. }}^{\prime}$ となるため, 式 （26）によって見積もられる $N_{1}$ は負の值を示すこととなる. さらに, ボブの長さ $L$ が長くなるにつれて簡易解析結果 $F_{\text {calc. }}^{\prime}$ が実験值 $F_{\text {exp. }}{ }^{\prime}$ および $\left(F^{\prime}-F_{\text {drop }}\right)_{\text {exp. }}$ よりも大きな值とな ることがわかる。これらは粘弾性流体の簡易解析に対して導 入した仮定の問題や考慮できていない影響因子の存在が原因 と考える. 特に粘弾性流体に対する入口・出口圧力損失の補 正方法については見直しが必要である。したがって，本報告 では入口・出口圧力損失による力 $F_{\text {drop }}$ を補正していない $F^{\prime}{ }_{\text {exp. }}$ を用い, 式 (27) より第一法線応力差 $N_{1}$ を評価する.

$$
N_{1}=\frac{F_{N 1}}{\pi R_{B}^{2}}=\frac{F^{\prime}-\left(F_{s s}+F_{s n}\right)}{\pi R_{B}^{2}}=\frac{F_{\text {exp. }}^{\prime}-F_{\text {calc. }}^{\prime}}{\pi R_{B}^{2}}
$$

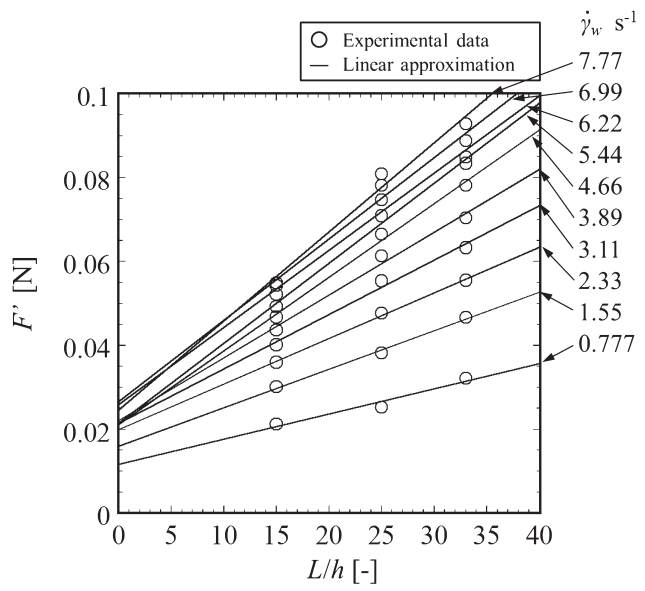

Fig. 10 Bagley plot of PAA0.2 wt $\%$.

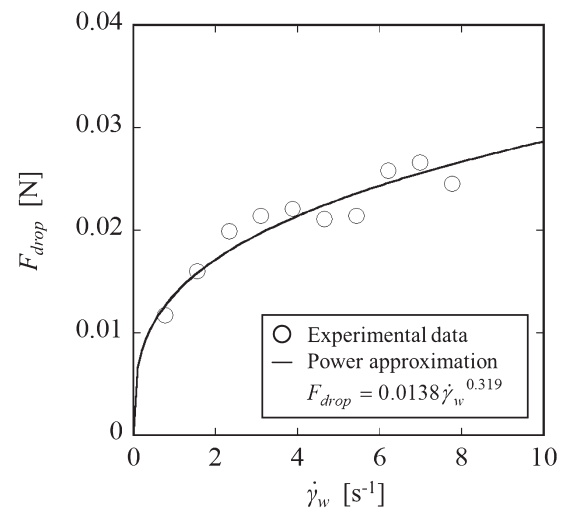

Fig. 11 Relationship between the force caused by the inlet and outlet pressure drop $F_{\text {drop }}$ and the shear rate at the wall $\dot{\gamma}_{w}$ of PAA $0.2 \mathrm{wt} \%$.
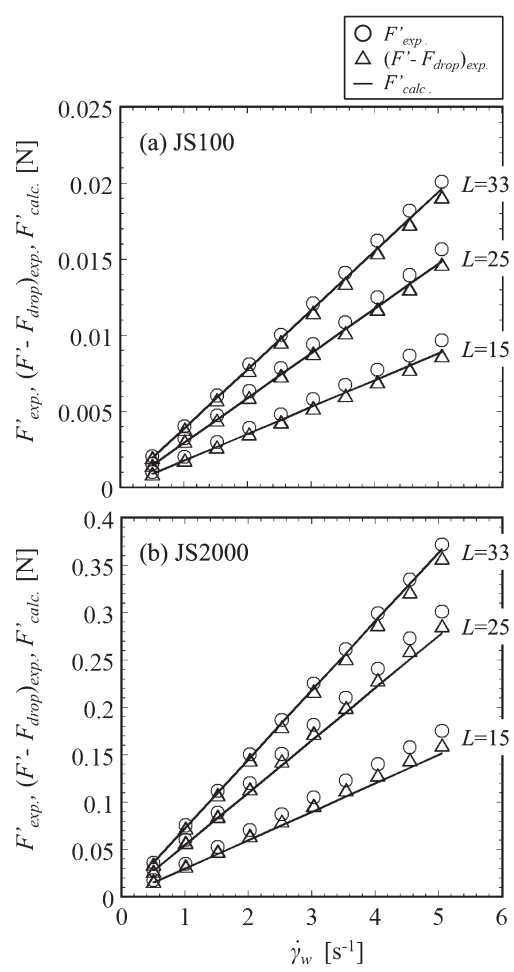

Fig. 12 Comparison between the measured resistant force and a calculated force $F_{\text {calc. }}^{\prime}$ of (a) JS100 and (b) JS2000.
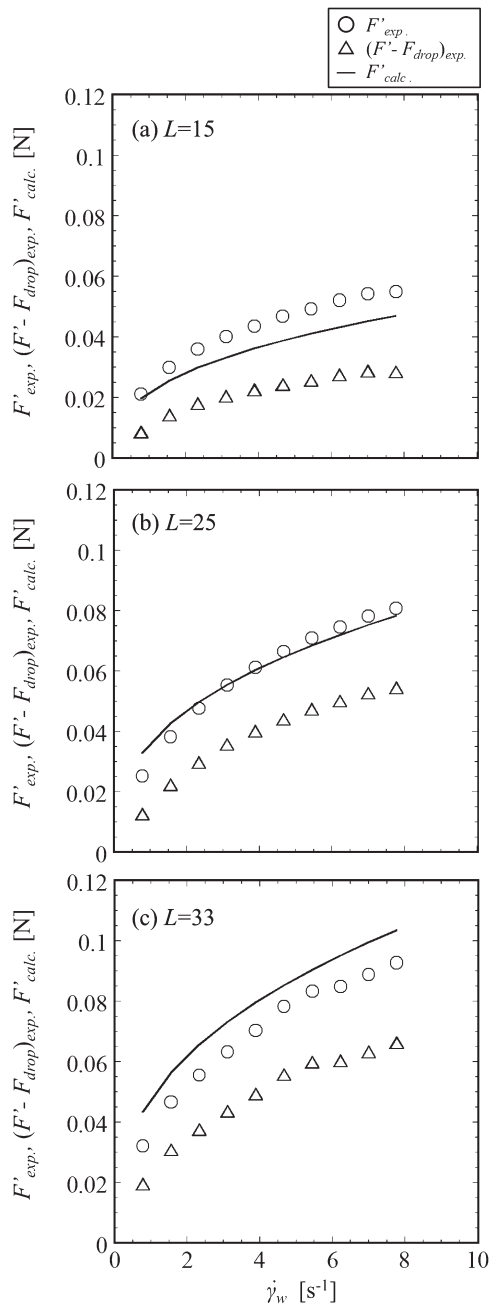

Fig. 13 Comparison between the measured resistant force and a calculated force $F_{c a l c}^{\prime}$ of PAA0.2 wt $\%$. 


\section{7. 領域 4 における第一法線応力差の評価}

Fig. 14 に式（27）より算出したPAA0.2 wt\%の第一法線応 力差 $N_{1}$ を示す。ここで, 塗り潰し記号は ARES-LS に円錐円 板型流路を取り付けて測定した $N_{1}$, そして, 破線は円錐円 板型流路で評価した $N_{1}$ をべき乗則で近似して低せん断速度 側に外挿した予測值を示す. Fig. 14 より同心二重円筒流路 の内円筒ボブに作用する押し込み反力から評価した $N_{1}$ はボ ブの長さが $L=15$ よりも $L=25$ で評価した值の方が破線の 予測值に近くなる。このことから， $L$ が大きくなると円錐円 板型流路の結果に近づく傾向があることがわかった．そして， $L=25$ で評価した $N_{1}$ は最も低いせん断速度の結果を除いて 円錐円板型流路の結果と定性的に一致した. 円錐円板型流路 によるトータル・スラスト法においてはスラストカを測定す るセンサーの精度の限界のため評価可能な最低せん断速度は $60 \mathrm{~s}^{-1}$ 程度であり，低せん断側の測定精度は低下する。これ に対し内円筒ボブの押し込みの場合, $L=15$ では二桁低いせ ん断速度 $0.5 \mathrm{~s}^{-1}$ まで評価できている。しかし, 評価された結 果は使用するボブの長さに依存しており, 特に $L=33$ では $N_{1}<0$ となった. 以上のことから, 本解析手法がトータル スラスト法では測定できない低せん断速度領域に適用できる こと, そして, 得られた結果がおよそ妥当な值であることを 示した。一方で，すき間への流入部・流出部の影響が無視で き，すき間内に理想的な流れ場が形成されている場合には $N_{1}$ はボブの長さ $L$ に依存しないと考えられること, さらに, 長さの異なるすべてのボブにおいて入口・出口圧力損失によ る力を補正することにより評価した $N_{1}$ が負の值となること など，不合理な結果も生じた。これらは導入した仮定に関す る妥当性の問題や見落としている影響因子の存在が原因と考 える. 特に本手法で用いたバグレイ・プロットによる入口・ 出口圧力損失の補正方法については再検討の必要がある。こ れらについては今後の検討事項とする.

\section{4. 結 言}

本報告では回転型レオメータをボブの押し込み動作で測定 するスライド型レオメータに転用し, ボブに作用する定常状 態における押し込み反力から第一法線応力差を評価した。 そ の結果, ボブの底面が試料の液面に接しない位置から一定の 速度で押し下げていく過程における反力の変化パターンは 6 つの領域に分けられることが明らかとなった。 また，バグレ イ・プロットを応用してニュートン流体の入口・出口圧力損 失による力を実験的に見積もることができた。ささらに, ニュートン流体では浮力と入口・出口圧力損失を補正した反 力の実験結果と簡易解析結果がよく一致した。粘弾性流体で ある PAA0.2 wt\% の場合, 長さ $25 \mathrm{~mm}$ のボブを用いて評価 した $N_{1}$ が円錐円板型流路の值と定性的に一致した。さらに, 同じレオメータを用いた円錐円板型流路による従来のトータ ル・スラスト法に対して二桁ほど低い低せん断速度領域にお ける評価が可能となった。 これらより, 本手法は既存の装置

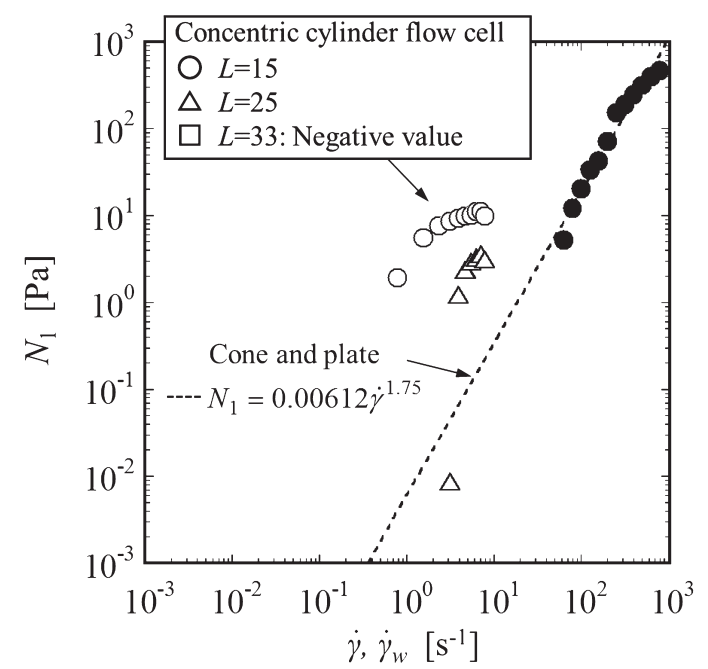

Fig. 14 Evaluated first normal stress difference $N_{1}$ of PAA0.2 wt $\%$ using the concentric cylinder flow cell in the zone 4.

をそのまま使用するだけで低粘度粘弾性流体の第一法線応力 差を測定できる可能性を明らかにした。一方で, 評価された $N_{1}$ におけるボブ長さの依存の発生といった不合理性もあり, 粘弾性流体に対する合理的な入口・出口圧力損失の補正方法 や影響因子の見直しを含めさらなる改善が必要である.

\section{REFERENCES}

1) Takahashi T, Kawano T, Shirakashi M, Proc. MECJ-06, 2332 (2006) (in Japanese).

2) Boger DV, Walters K, "Rheological Phenomena in Focus", (1993), Elsevier Science Publishers B.V., NL.

3) Nihon Reoroji Gakkai, "Koza Reoroji”, (1992), Kobunshi Kankokai, Kyoto (in Japanese).

4) Takahashi T, Fuller GG, Rheologica Acta, 35, 297-302 (1996).

5) Hasegawa T, Trans Japan Society of Mech Eng, 44 (381), 1606-1615 (1978) (in Japanese).

6) Nakamura K, "Non-Newtonian Fluid Mechanics", (1997), Corona Publishing Co., Ltd, Tokyo (in Japanese).

7) Sugihara Y, Kubota W, Yoshitake Y, Takahashi T, Iwata S, Nagumo R, Mori H, Nihon Reoroji Gakkaishi (J Soc Rheol Jpn), 44, 175-183 (2016) (in Japanese).

8) Suzuki K, Nippon Shokuhin Kagaku Kogaku Kaishi, 46, 657663 (1999) (in Japanese).

9) Suzuki K, Imaoka K, Keawkaika S, Hagura Y, Japan Journal of Food Engineering, 8, 73-80 (2007).

10) Münstedt H, Schwarzl FR, "Deformation and Flow of Polymeric Materials”, (2014), Springer, DE. 